Review

\title{
Functional Channel Membranes for Drinking Water Production
}

\author{
Alfredo Gonzalez-Perez ${ }^{1,2, *(1), \text { Kenneth M. Persson }}{ }^{3}$ and Frank Lipnizki 4 \\ 1 Sweden Water Research AB, Ideon Science Park, Scheelevägen 15, 22370 Lund, Sweden \\ 2 Membrane Biophysics Group, Niels Bohr Institute, University of Copenhagen, Blegdamsvej 17, \\ 2100 Copenhagen $\varnothing$, Denmark \\ 3 Division of Water Resources Engineering, Faculty of Engineering LTH, Lund University, John Ericssons \\ Väg 1, V-Hus, 22100 Lund, Sweden; kenneth_m.persson@tvrl.lth.se \\ 4 Department of Chemical Engineering, Faculty of Engineering LTH, Lund University, Naturvetarvägen 14, \\ Box 124, 22100 Lund, Sweden; frank.lipnizki@chemeng.lth.se \\ * Correspondence: alfredogp@gmail.com or alfredo.gonzalez-perez@swrab.se or gonzalez@nbi.ku.dk; \\ Tel.: +46-072-589-0981
}

Received: 15 May 2018; Accepted: 26 June 2018; Published: 28 June 2018

\begin{abstract}
Drinking water production utilities rely on, among other processes, different filtration technologies like bank filtration and slow sand filters, as well as pressure, roughing, or rapid gravity filters that, together with low- and high-pressure operating membranes, help to ensure high quality drinking water for millions of customers all over the world. The global market of membrane separation technologies is projected to reach USD 11.95 Billion by 2021, encompassing water treatment, wastewater treatment, food and beverage processing, industrial gas processing, and pharmaceutical and biomedical applications. In addition to the current, polymer-based membrane separation technologies, new promising strategies using embedded functional motifs, water and ion channels, are expected to play a key role in the next generation of membranes for separation purposes, which are of paramount relevance for drinking water production utilities. In this review, we summarize the different strategies for developing new advanced membranes with a wide variety of functional motifs, like biological and artificial water and ion channels, and their possible impact on drinking water applications.
\end{abstract}

Keywords: drinking water membranes; reverse osmosis; water-channels; ion-channels; aquaporins; carbon nanotubes; peptides; cyclodextrins; calixarenes; graphene

\section{Introduction}

Safe and accessible drinking water remains an issue of major concern throughout the world. According to the WHO fact-sheet, $89 \%$ of the world's population used an improved drinking-water source at the end of 2011. However, an estimated 768 million people did not use an improved source for drinking water, while 185 million people relied on surface water to meet their daily drinking-water needs. Advances in management as well as technology tools for drinking-water production, distribution, and wastewater treatment, together with appropriate policy and specific water-related programs, helped to substantially improve the accessibility of safe drinking-water for many people all over the world.

According to the current agenda of the United Nations for sustainable development 2030, water represents a pivotal issue for several of the 17 sustainable development goals. However, in particular, goal number 6 states the intention to "ensure availability and sustainable management of water and sanitation for all". Furthermore, point 6.a highlights the importance of expanding international cooperation with developing countries in water- and sanitation-related activities and 
programs, including water harvesting, desalination, water efficiency, wastewater treatment, recycling, and resource technology. Many of these activities rely on the systematic use of membrane technologies for desalination, wastewater treatment, water recycling, and in general, for drinking-water production. Membranes play a pivotal role in drinking water production. Hence, their price is a key factor that makes the technology inaccessible for poor countries. The development of new membranes that can reduce cost will help to achieve sustainable development goals.

Membranes are typically made of polymeric, organo-mineral, ceramic, or metallic materials related to a variety of filtration techniques characterized by different pore-size (ranging from dense to porous membranes). Depending on the pore-size and typical pressure requirements, the key membranes can be classified as one of microfiltration ( 2 to $0.1 \mu \mathrm{m}$ and 1-4 bar), ultrafiltration (0.1 to $0.005 \mu \mathrm{m}$ and 2-7 bar), nanofiltration (0.005 to $0.0005 \mu \mathrm{m}$ and $>6$ bar), and reverse osmosis $(<0.5 \mathrm{~nm}$ and $>10$ bar). These membranes are used for different tasks depending of the type of dissolved and suspended components to be rejected. Hence, microfiltration is used to reject suspended particles, ultrafiltration to reject bacteria and viruses, and nanofiltration and reverse osmosis to reject dissolved components e.g., salts.

Non-solvent induced phase separation (NIPS) and thermally induced phase separation (TIPS) are the two most common fabrication methods for polymeric membranes, which are represent $85-95 \%$ of the current membrane market. There are many reviews and books devoted to the different fabrication methods, as well as their specific issues [1-6]. This information is outside of the scope of the current review.

It is foreseen that new, advanced membrane technologies will play a dominant role in the future of production capabilities, management, and operation of drinking-water and waste-water utilities. These technologies will have a further significant impact on different separation duties in a wide range of industries, including among others, beverage, health care, food processing, and microchip fabrication. The success of these new technologies depends not only on their suitability in lab operations, but also on their suitability for an increasingly demanding market, in which economic and regulatory factors will play a dominant role in the possibility of developping and commercializing new membrane technologies.

The current review will summarize the different strategies taken for ion-channel or water-channel incorporation into membranes, with potential uses in drinking water production. A water-channel is a molecular pore that is selective to the flow of water, while ion-channels are molecular pores which are selective to the flow of one or more specific ionic species (anions or cations). Both can potentially be used as functional motifs to purify water. Most of this work has been done at a very fundamental level over lipid- or polymer-based supports. The relevance of artificial water channels was highlighted by Barboiu [7], while other natural strategies like the use of Aquaporins have been summarized in several reviews and books chapters [8-10]. The path from fundamental development towards an industrial application is long and will require further research. This review will discuss different functional motifs divided between water-channels and ion-channels, both naturally and artificially made. It is expected that in the future, these new membranes will take their place among the reverse osmosis, nanofiltration, electrodialysis, and forward osmosis processes, covering pore sizes between $1 \AA$ and $10 \mathrm{~nm}$. Different issues associated with practical membrane feasibility, steps towards commercialization, policy and regulations, and other relevant issues for industry will be highlighted. Nowadays, most of these membranes are in a low TRL level (Technology Readiness Level), and cannot be compared with current commercial membranes. Whether these new emerging functional membranes with wateror ion-channels will reach the market will depend on many factors, and the aim of this review is to describe the present situation, as well as to highlight some development challenges on the path to commercialization. 


\section{Membranes with Water Channels}

The incorporation of water channels as functional motifs in membranes for drinking water production or wastewater treatment are a natural option for the development of new functional membranes. A recent feature article summarizing developments of artificial water channels was published by Barboiu [11]. The number of new water motifs used in fundamental science is continuously increasing. While the specificity of the channels for water is not always ensured, other ion channels had been proven to be suitable for water filtration on a laboratory scale. There is still a long path ahead before these functional motifs become a standard in the water industry. In the following sections, the most promising systems are being highlighted.

\subsection{Aquaporins}

Aquaporins (AQPs) can be incorporated into a single bilayer membrane (lipid or polymer-based) or encapsulated into vesicles with AQPs into a dense polymer matrix [12]. The first approach results in low mechanical stability and salt rejection, while the second has other drawbacks related to e.g., ionic leakage and vesicle packing. Further research is required to overcome all inherent problems [13], but on the other hand, Aquaporin A/S (Denmark) and its Chinese joint venture Aquapoten have started to commercialize tap water reverse osmosis elements for household water purifiers with AQPs immobilized in a polymer layer. Mangrove Membranes, a subsidiary of Applied Biomimetic, focuses its operations on Aquaporin production, as well as on the development of biomimetic polymeric membranes suited to functional membrane protein reconstitution. The company operates in Denmark and the USA, and sells different membrane modules, with a special focus on dairy in industry, selling AB DairySep ${ }^{\mathrm{TM}}$ UF Dairy.

Wang et al. [14] developed the biomimetic nanofiltration (NF) membrane by immobilizing an Aquaporin Z (AqpZ)-incorporated supported lipid bilayer (SLB) on a layer-by-layer (LbL) complex polyelectrolyte membrane to achieve excellent permeability and salt rejection with a high stability. The main advantage of this approach is the Aquaporin incorporation methodology that is easy to apply compared with other reconstitution methods.

More recently, Xia et al. [15] reported on designed and commercially available the Aquaporin Inside flat-sheet membrane, developed for forward osmosis (FO) by Aquaporin A/S, Lyngby, Denmark. A study on the AQP membranes found them to exhibit water and reverse solute flux performances similar to those of other commercially available FO membranes.

However, the use of AQPs in membranes remains challenging, due to the lack of an effective strategy to stabilize AQPs and fabricate robust membranes. In a recent article, He et al. [16] reported the utilization of an amphiphilic peptide (BP1) to successfully stabilize AQPs, and used the resulting protein-BP1 complex for desalination purposes. Gonzalez-Perez et al. [17] investigated the stability of AQP in polymersomes using ABA triblock copolymers with poly(dimethylsiloxane) and poly(2-methyloxazoline) blocks. The stability that can be achieved under precise lab conditions may not be possible under real conditions using seawater, wastewater, or other common water sources. Another key problem for Aquaporin-based membranes is to keep the membrane functional at a wide range of temperatures. Aquaporins operate inside living organisms, and are optimized by nature to be functional in a limited range of temperatures. Industrial applications will need to ensure stability under a wider range of temperatures. The temperature issue, together with the mechanical integrity of the membranes, are two key challenges which need to be addressed.

The success of the Aquaporin-based membranes will strongly depend of keeping a low production cost and better filtration performance than the existing membranes on the market. How these new membranes will cope with unavoidable fouling problems that characterize all membranes given enough operation time remains to be seen. Conventional cleaning methods will certainly affect the aquaporin functionality, and it is most likely that innovative approaches for dealing with fouling on these membranes will need to be developed. 


\subsection{Carbon Nanotubes and Other Unimolecular Channels}

Carbon nanotube (CNT) membranes have been recently highlighted by Das et al. [18] for the next generation water desalination, while the advances, challenges, and opportunities have been summarized by Kar et al. [19], and more recently by Lee et al. [20]. Due to high water permeability-on the order of $9.0 \times 10^{8}$ water molecules per second and channel [21]—it has been getting increasing attention as a suitable system for water filtration. Carbon nanotubes can be incorporated into solid-state membranes or soft polymeric ones. This possibility yields substantially more mechanical stability than that of Aquaporin-based membranes. If pressure is needed for the water to flow in a specific direction, as happens in RO processes, the mechanical stability of the membrane is of paramount relevance.

Lee et al. [22] developed a millimeter-thick ultrafiltration membrane using carbon nanotubes that can provide water permeability that approaches $30,000 \mathrm{~L} \mathrm{~m}^{-2} \mathrm{~h}^{-1} \mathrm{bar}^{-1}$, compared to the best water permeability of $2400 \mathrm{~L} \mathrm{~m}^{-2} \mathrm{~h}^{-1} \mathrm{bar}^{-1}$ reported for carbon nanotube membranes. Experimental results revealed that the permeance increases as the pore size decreases, while the carbon nanotube walls of the membrane impede bacterial adhesion and resist biofilm formation. This represents a key step forward towards the total avoidance of fouling, making this approach a very attractive one for further development.

Song et al. [23] recently investigated the effect of carbon nanotube (CNT) location on the property and performance of membranes. Four different types of membranes were prepared, including (1) thin film composite (TFC, polyamide active layer on polysulfone substrate), (2) nanocomposite-supported thin film composite (nTFC, polyamide active layer on CNT-embedded polysulfone substrate), (3) thin film nanocomposite (TFN, CNT-incorporated polyamide active layer on polysulfone substrate), and (4) nanocomposite-supported thin film nanocomposite (nTFN, CNT-incorporated polyamide active layer on CNT-embedded polysulfone substrate). Their results showed a water permeability following the sequence: nTFN $>$ TFN $>$ nTFC $>$ TFC. Different membrane configurations may also display different mechanical stability, and high mechanical stability should be accompanied by good water permeability, i.e., suitable for water filtration purposes.

Pillar[5]arenes have been also used as unimolecular water channels embedded in bilayer membranes. Si et al. [24] reported the first examples of those artificial water channels using polyhdrazide-pillar[5]arenes that are able to form h-bonded tubular structures displaying low permeability. In a more recent paper, Shen et al. [25] developed the next generation of these compounds, adding hydrophobicity to the molecule using peptide attached motifs. While the first generation of Pillar[5]arenes showed low permeability [24,26,27], in the order of 40 water molecules per second per channel, the latest generation developed by Shen et al. [25] showed permeability in the range of Aquaporins and carbon nanotubes, achieving $3.5 \times 10^{8}$ water molecules per second per channel. Despite their good performance in comparison with Aquaporin-based membranes, there is still no single product available on the market; this indicates a long road ahead towards the development of a working membrane suited for market applications.

Furthermore, cyclic peptide nanotubes have been tested for water permeation. In a recent paper, Maroli et al. [28] studied the structure, stability, and water permeation of the ([D-Leu-L-Lys-(D-Gln-L-Ala) $\left.{ }^{3}\right]$ ) cyclic peptide on different phospholipid bilayers using $100 \mathrm{~ns}$ independent molecular dynamics (MD) simulations. However, the authors found that the permeation coefficients demonstrated that water flow in the channel relies upon the environment, which limits their possible applications. This approach is interesting for increasing our overall knowledge of the incorporation of functional motifs as artificial water channels. However, their dependence on environment for suitable water permeability substantially limits their applicability.

\subsection{Self-Assembled Channels}

The number of self-assembled channels devoted exclusively to water permeation is limited. However, due to the versatile fabrication process of those channels, more development is expected in the near future. Some of the most relevant existing, self-assembled channels are highlighted here. 
Despite their potential for developing suitable membranes for water filtration, currently, no commercial membranes have been developed using this approach.

Dendritic dipeptides self-assembled via pi-stacking, which generate stable helical pores of $14.5 \mathrm{~A}$ diameter $[29,30]$, are suited for water transport, and have resulted in a variety of water channels based on supramolecular polymers; see the recent review by Krieg et al. [31].

Imidazole-Quartet Water and Proton Dipolar Channels have been reported by Le Duc et al. [32]. The authors used ureido imidazoles 1 and 2 to construct I-quartets mutually stabilized by inner water dipolar wires, reminiscent of G-quartets stabilized by cation templating. The encapsulated water molecules form one H-bond with the inner wall of the I-quartet nanotube, and one with an adjacent water molecule. However, water specificity was not found, as water molecules and protons can permeate bilayer membranes through I-quartet channels, as the authors comment.

Self-assembling sub-nanometer pores with unusual mass-transport properties have been developed, as reported by Zhou et al. [33]. In their work, the authors report a strategy for enforcing the nanotubular assembly of rigid macrocycles in both the solid state and solution, based on the interplay of multiple hydrogen-bonding and aromatic $\pi-\pi$ stacking interactions.

Water-Binding Foldamers have been used by Ong et al. [23] to encapsulate water dimers. The molecules form hydrophobic helical channels by pi-stacking of aromatic units. Most recently, a series of indolocarbazole-pyridine (IP) oligomers were prepared that fold into helical conformations, and their folding features in solution and in the solid state were prepared by [34]. These oligomers form molecular tubes containing one-dimensional water chains.

All the systems suggested in the last three paragraphs have limitations related with the use of lipid membranes as a support for reconstitution. Lipid membranes are mechanically unstable and cannot be used directly as a water filtration membrane that, in the case of $\mathrm{RO}$, needs to stand high pressures. It is still interesting to mention that the same reconstitution approach could be use on polymer-based membranes that mimic the ABA structure of lipid membranes $(\mathrm{A}=$ hydrophylic, $\mathrm{B}=$ hydrophobic $)$ but display high mechanical stability. The incorporation of lipid-based membranes into a polymeric matrix could improve the mechanical stability and represent an alternative to direct reconstitution in pure polymeric membranes. So far, no membranes have been developed using this approach for commercial applications.

\section{Membranes with Ion Channels}

Drinking water production relies upon the production of water with the right balance of ions in a way that is acceptable for human consumption. Membranes that selectively remove or concentrate ions can be used under specific conditions to achieve an ionic water balance, cleaning polluted water. The number of artificial ion channels reported is large, and it is out of the scope of the current review, with a wide variety of supramolecular structures like cyclodextrins, calixarenes, helical and cyclic peptides, crown ethers, metal-organic, and hydrogen bonded frameworks, among others. In the following paragraphs, some artificial ion-channel structures are discussed as a possible tool for selective ion removal from polluted water. This may have interesting industrial applications; for example, for ion-recovery in some industrial processes, or pollutant removal in the mining industry. A good example of a side-application of $\mathrm{RO}$ utilities could be the extraction of Lithium ions, that are abundant in seawater. This has implications for the mining industry, which uses chemical treatments to extract lithium from rocks and brines [35].

\subsection{Cyclodextrins and Calixarenes}

Cyclodextrins have been identified for a wide range of applications that have been summarized by many authors in books and reviews [36-41]. It has been proven that half-channel derivatives of cyclodextrins provide a suitable approach to create artificial active ion channels. This strategy has been highlighted and summarized in a recent review by Chui and Fyles [42]. However, irregular conductances rooted in defects on the membranes may limit their applicability for the 
selective removal of specific ions. The difficulties associated with preparing a sealed membrane keeping cyclodextrins as a single functional channel makes it difficult to apply this technology to drinking water production. More research needs to be done to develop alternative membrane supports suited to water filtration applications.

Transmembrane ion transport by calixarenes and their derivatives was investigated by [43]. These macrocycle molecules are suited for size-based ion recognition, with membrane-spanning substituents that allow the target ions to traverse a phospholipid bilayer. An artificial sodium ion channel from calix[4]arene was studied by Lawal et al. [44]. In their work, the authors confirmed with lipid bilayer experiments that 1,3-alt calixarene functions as an artificial transmembrane ion in the presence of $\mathrm{Na}^{+}$, but not $\mathrm{K}^{+}$. Calix[4]arene-based ligands have been shown to be voltage-dependent potassium channels [45]. More recently, chloride transport has been investigated using a calix[4]arene derivative in a DOPC bilayer [46]. Calixarenes are an interesing approach; they somehow inherit the aforementioned structural problems of cyclodextrins.

Interesting specific ions like chloride and sodium are present in high concentrations in seawater, while other ions present in the taling ponds of mining operations are examples to be targeted by artificial ion channels incorporated into robust membranes for selective removal and concentration. The possibilities for cylodextrins and calixarenes to supply a cheap and robust solution for ion removal are still to be explored, and operational membranes to be developed and tested.

\subsection{Peptide Nanotubes}

The use of natural and artificial peptides as alternatives to ion water channels have attracted considerable attention because of their potential use in a wide range of areas, like material science, sensor development, biomedical, pharmaceutical, and environmental applications etc. [47-50]. Embedded into reconstituted biological membranes, artificial polymer-based alternatives, or in solid or soft supports, peptides can be fabricated, and their properties tuned to match the needs of a wide variety of specific applications $[51,52]$. Cyclic and helical peptides are a good way to prepare artificial ion channels to be incorporated into lipid or polymeric membranes [52].

Pore- and channel-forming peptides and their mimetics were recently summarized by Fandinho [53]. The use of peptides for pore formation was, together with proteins, synthetic organic compounds, and DNA, recently reviewed by Howorka [54]. Gramidin has inspired research on peptide pore formation and its application as an ion channel; even water permeability has been investigated on this biological channel [55]. Recent studies by Saeki et al. [56] showed the possibility of using a supported lipid bilayer with gramicidin A water channel for reverse osmosis.

This approach is one of the most promising, because peptides are easy and cheap to produce, and their chemical structure is known in a very precise way. They can be incorporated both in lipid and polymeric membranes, and the studies don't need to rely on keeping specific biological conditions that will limit the range of applicability. Peptides represent an open road for developing artificial membranes for water filtration, with a focus on specific ions that need to be removed. The applications for environmental remediation when ionic species pollute water reservoirs are of special interest. Chemical and mechanical stability can be tuned during synthesis, and in principle, there is no limitation for reconstitution in abiotic environments like polymer-based membranes of matrix composites. Stability at a wide range of temperatures can be achieved by giving the peptide the right chemical configuration, resulting in plenty of room for innovation and development of membranes for unconventional applications.

\subsection{Other Artificial Ionic Channels}

Membrane nanopores can be built using different strategies. A recent review summarizing different approaches was publised by Howorka [54]. In this review, the author critically compared the characteristics of the different building materials, and explored the influence of building material on pore structure, dynamics, and function. Some interesting examples of artificial ion channels that 
distinguish themselves from those previously highlighted are shown here. For a more comprehensive description, a recent review on the current advances of nanoporous membranes for water purification was published by Wang et al. [57].

Recently, artificial channels with two distinct conductance states have been created using a metal-organic porous molecule, namely coboctahedra [58]. The open pore time of each conductance state through distinct apertures, and the switching between them, can be controlled. This opens interesting possibilities to promote active control of cell signaling, or channelopathy, as the authors mention, but also, the selective removal of ions in polyionic solutions present in, for example, some wastewater produced in mining operations.

The use of DNA as a tool to form nanochannels is another interesting strategy [59]. In a recent paper, Göpfrich et al. [60] showed transmembrane porins made from DNA origami that display large-conductance. The authors used DNA to build the largest synthetic pore in a lipid membrane to date. The incorporation was achieved using 19 cholesterol tags to anchor a megadalton funnel-shaped DNA origami porin in a lipid bilayer membrane.

Water purification through nanoporous graphene has been proposed, and an example by Cohen-Tanugi and Grossman [61] using molecular dynamics was published. In their work, the authors showed that nanometer-scale pores in single-layer freestanding graphene can effectively filter $\mathrm{NaCl}$ from water. Additionally, a review of different wto-dimensional nanostrutures, highlighting graphene for water purification, was recently published by Dervin et al. [62].

Heiranian et al. [63] recently demonstrated, with the support of simulations, that a nanopore in a single-layer molybdenum disulfide could effectively reject ions, and allow transport of water at a high rate. The authors concluded that pores with only molybdenum atoms on their edges led to higher fluxes, which are $\sim 70 \%$ greater than those of graphene nanopores. This single-layer $\mathrm{MoS}_{2}$ nanopore could be a promising tool for water desalination. However, practical studies need to be developed to confirm the predictions of these simulations.

\section{Future Development}

The road to the commercialization of membranes with functional channels for drinking water is full of promises and challenges. The use of functional motifs, with or without specificity, embedded in a suitable support, will reduce membrane production cost, and potentially increase selectivity on the ionic species to be removed. Drinking water production utilities will certainly benefit from this innovative technology, that promises to reduce costs and increase efficiency. In the following paragraphs, some of the key challenges will be highlighted.

The cost of the membranes, in particular for drinking water, is a challenge. Current membranes are based on commodity polymers like polysulphone/polyethersulphone, polyamide, and cellulose. Future membranes must be competitive, either directly from a cost base, or from a cost-flux/productivity perspective. However, to utilize the higher fluxes based on the functional channels, new module concepts are required to promote sufficient turbulence to minimize the effects of concentration polarization in an energy-efficient way. In other words, a high flux membrane requires a suitable module in order to utilize its potentials. Furthermore, it should be noted that high flux does not eliminate the effect of the osmotic pressure required to purify water from e.g., salt water.

Another important aspect is the scalability of the membrane and its production. As Rickard Baker [64] recently highlighted, the production of a $50 \mathrm{~cm}^{2}$ membrane might be sufficient for a good publication, but on an industrial scale, thousands to millions $\mathrm{m}^{2}$ of membranes need to be produced in a consistent way. Hence, it is important that the membrane production concept is scalable.

Furthermore, the life cycle of current polymeric membranes is typically in the range of one to five years, depending on the application. Thus, long-term stability testing is an important aspect in the development of new membranes. During the life cycle, the membrane should be inert, to prevent any leaching of membrane material and a loss of functionality. 
The membrane material and the resulting membranes have to be further suitable for certification by national and international bodies, such as NSF International (The Public Health and Safety Company), for drinking water elements for the US market.

Retention of solutes must be kept at a high and stable level throughout the lifetime of the membranes. A loss in retention is devastating for the performance of membranes, and reduces the reliability of the process significantly. To facilitate applications of functional channel membranes, the industry must prove trustworthiness in pilot and full-scale applications in a broad perspective. Then, necessary life-cycle cost, and similar methods to compare the performance of different functional channel membranes with standard membrane technologies, can be established. Such techno-economical charts are essential, and would lead to a broader use of functional channel membranes in the market.

Finally, during the membrane life cycle, it is nearly impossible to avoid membrane fouling. Hence, membrane cleaning is an important part of membrane operation on industrial scale, where cleaning may take place every week, and sometimes every day. To have efficient cleaning, he membranes are typically exposed to temperatures of up to $60^{\circ} \mathrm{C}$, and extreme $\mathrm{pHs}$ in the range of $2-10$, for standard RO membranes. These conditions are required to achieve sufficient sanitization. It should be noted that, in particular free-chlorine, one of the most efficient and common disinfectants in the water industry, is not compatible with standard polyamide-based RO membranes; a potential gap for future RO materials and membranes.

Overall, in order to be successful in the market, research on functional channels has to address these challenges on the way to commercialization.

Author Contributions: All the authors contributed with equally in the preparation of this review.

Funding: This research was funded by Vinnova grant number 2018-00324.

Acknowledgments: The authors would like to acknowledge Vinnova-Swedish Innovation Agency-to support this review as part of MemClean project (Reference number 2018-00324). A G-P would like to acknowledge Thomas Heimburg from the Niels Bohr Institute for the access to the facilities at the Membrane Biophysics Group.

Conflicts of Interest: The authors declare no conflict of interest. The founding sponsors had no role in the design of the study; in the collection, analyses, or interpretation of data; in the writing of the manuscript, and in the decision to publish the results.

\section{References}

1. Lalia, B.S.; Kochkodan, V.; Hashaikeh, R.; Hilal, N. A review on membrane fabrication: Structure, properties and performance relationship. Desalination 2013, 326, 77-95. [CrossRef]

2. Mohammad, A.W.; Teow, Y.H.; Ang, W.L.; Chung, Y.T.; Oatley-Radcliffe, D.L.; Hilal, N. Nanofiltration membranes review: Recent advances and future prospects. Desalination 2015, 356, 226-254. [CrossRef]

3. Altaee, A.; Sharif, A. Pressure retarded osmosis: Advancement in the process applications for power generation and desalination. Desalination 2015, 356, 31-46. [CrossRef]

4. Amy, G.; Ghaffour, N.; Li, Z.; Francis, L.; Linares, R.V.; Missimer, T.; Lattemann, S. Membrane-based seawater desalination: Present and future prospects. Desalination 2017, 401, 16-21. [CrossRef]

5. Singh, R. Membrane Technology and Engineering for Water Purification-Application, Systems Design and Operation. In Hybrid Membrane Systems for Water Purification; Butterworth-Heinemann: Oxford, UK, 2015; pp. 57-130.

6. Buonomenna, M.G.; Golemme, G. Advanced Materials for Membrane Preparation; Bentham eBooks: Sharjah, UAE, 2012.

7. Barboiu, M. Artificial Water Channels. Angew. Chem. Int. Ed. 2012, 51, 11674-11676. [CrossRef] [PubMed]

8. Tang, C.; Wang, Z.; Petrinić, I.; Fane, A.G.; Hélix-Nielsen, C. Biomimetic aquaporin membranes coming of age. Desalination 2015, 368, 89-105. [CrossRef]

9. Tang, C.Y.; Zhao, Y.; Wang, R.; Hélix-Nielsen, C.; Fane, A.G. Desalination by biomimetic aquaporin membranes: Review of status and prospects. Desalination 2013, 308, 34-40. [CrossRef] 
10. Abdelrasoul, A.; Doan, H.; Lohi, A. Aquaporin Biomimetic Membranes. In Biomimetic and Bioinspired Membranes for New Frontiers in Sustainable Water Treatment Technology; InTech: London, UK, 2017.

11. Barboiu, M. Artificial water channels-Incipient innovative developments. Chem. Commun. 2016, 52, 5657-5665. [CrossRef] [PubMed]

12. Habel, J.; Hansen, M.; Kynde, S.; Larsen, N.; Midtgaard, S.R.; Jensen, G.V.; Bomholt, J.; Ogbonna, A.; Almdal, K.; Schulz, A.; et al. Aquaporin-Based Biomimetic Polymeric Membranes: Approaches and Challenges. Membranes 2015, 5, 307-351. [CrossRef] [PubMed]

13. To, J.; Torres, J. Can Stabilization and Inhibition of Aquaporins Contribute to Future Development of Biomimetic Membranes? Membranes 2015, 5, 352-368. [CrossRef] [PubMed]

14. Wang, M.; Wang, Z.; Wang, X.; Wang, S.; Ding, W.; Gao, C. Layer-by-Layer Assembly of Aquaporin Z-Incorporated Biomimetic Membranes for Water Purification. Environ. Sci. Technol. 2015, 49, 3761-3768. [CrossRef] [PubMed]

15. Xia, L.; Andersen, M.F.; Hélix-Nielsen, C.; McCutcheon, J.R. Novel Commercial Aquaporin Flat-Sheet Membrane for Forward Osmosis. Ind. Eng. Chem. Res. 2017, 56, 11919-11925. [CrossRef]

16. He, Y.; Hoi, H.; Abraham, S.; Montemagno, C.D. Highly permeable biomimetic reverse osmosis membrane with amphiphilic peptide stabilized aquaporin as water filtering agent. J. Appl. Polym. Sci. 2018, 135, 46169. [CrossRef]

17. González-Pérez, A.; Persson, K.M.; Taboada, P. Structural stability of SoPIP2;1 aquaporin under reconstitution in polymersomes. J. Mol. Liq. 2018, 257, 26-31. [CrossRef]

18. Das, R.; Ali, M.E.; Hamid, S.B.A.; Ramakrishna, S.; Chowdhury, Z.Z. Carbon nanotube membranes for water purification: A bright future in water desalination. Desalination 2014, 336, 97-109. [CrossRef]

19. Kar, S.; Bindal, R.C.; Tewari, P.K. Carbon nanotube membranes for desalination and water purification: Challenges and opportunities. Nano Today 2012, 7, 385-389. [CrossRef]

20. Lee, J.; Jeong, S.; Liu, Z. Progress and challenges of carbon nanotube membrane in water treatment. Crit. Rev. Environ. Sci. Technol. 2016, 46, 999-1046. [CrossRef]

21. Holt, J.K.; Park, H.G.; Wang, Y.; Stadermann, M.; Artyukhin, A.B.; Grigoropoulos, C.P.; Noy, A.; Bakajin, O. Fast Mass Transport Through Sub-2-Nanometer Carbon Nanotubes. Science 2006, 312, 1034-1037. [CrossRef] [PubMed]

22. Lee, B.; Baek, Y.; Lee, M.; Jeong, D.H.; Lee, H.H.; Yoon, J.; Kim, Y.H. A carbon nanotube wall membrane for water treatment. Nat. Commun. 2015, 6, 7109. [CrossRef] [PubMed]

23. Song, X.; Wang, L.; Mao, L.; Wang, Z. Nanocomposite Membrane with Different Carbon Nanotubes Location for Nanofiltration and Forward Osmosis Applications. ACS Sustain. Chem. Eng. 2016, 4, 2990-2997. [CrossRef]

24. Si, W.; Chen, L.; Hu, X.-B.; Tang, G.; Chen, Z.; Hou, J.-L.; Li, Z.-T. Selective Artificial Transmembrane Channels for Protons by Formation of Water Wires. Angew. Chem. Int. Ed. 2011, 50, 12564-12568. [CrossRef] [PubMed]

25. Shen, Y.; Si, W.; Erbakan, M.; Decker, K.; De Zorzi, R.; Saboe, P.O.; Kang, Y.J.; Majd, S.; Butler, P.J.; Walz, T.; et al. Highly permeable artificial water channels that can self-assemble into two-dimensional arrays. Proc. Natl. Acad. Sci. USA 2015, 112, 9810-9815. [CrossRef] [PubMed]

26. Si, W.; Xin, P.; Li, Z.-T.; Hou, J.-L. Tubular Unimolecular Transmembrane Channels: Construction Strategy and Transport Activities. Acc. Chem. Res. 2015, 48, 1612-1619. [CrossRef] [PubMed]

27. Xin, P.; Zhu, P.; Su, P.; Hou, J.-L.; Li, Z.-T. Hydrogen-Bonded Helical Hydrazide Oligomers and Polymer That Mimic the Ion Transport of Gramicidin A. J. Am. Chem. Soc. 2014, 136, 13078-13081. [CrossRef] [PubMed]

28. Maroli, N.; Kolandaivel, P. Structure, stability and water permeation of ([D-Leu-L-Lys-(D-Gln-L-Ala) 3$]$ ) cyclic peptide nanotube: A molecular dynamics study. Mol. Simul. 2018, 44, 225-235. [CrossRef]

29. Percec, V.; Dulcey, A.E.; Balagurusamy, V.S.K.; Miura, Y.; Smidrkal, J.; Peterca, M.; Nummelin, S.; Edlund, U.; Hudson, S.D.; Heiney, P.A.; et al. Self-assembly of amphiphilic dendritic dipeptides into helical pores. Nature 2004, 430, 764-768. [CrossRef] [PubMed]

30. Percec, V.; Dulcey, A.E.; Peterca, M.; Adelman, P.; Samant, R.; Balagurusamy, V.S.K.; Heiney, P.A. Helical Pores Self-Assembled from Homochiral Dendritic Dipeptides Based on l-Tyr and Nonpolar $\alpha$-Amino Acids. J. Am. Chem. Soc. 2007, 129, 5992-6002. [CrossRef] [PubMed]

31. Krieg, E.; Bastings, M.M.C.; Besenius, P.; Rybtchinski, B. Supramolecular Polymers in Aqueous Media. Chem. Rev. 2016, 116, 2414-2477. [CrossRef] [PubMed] 
32. Le Duc, Y.; Michau, M.; Gilles, A.; Gence, V.; Legrand, Y.-M.; van der Lee, A.; Tingry, S.; Barboiu, M. Imidazole-Quartet Water and Proton Dipolar Channels. Angew. Chem. Int. Ed. 2011, 50, 11366-11372. [CrossRef] [PubMed]

33. Zhou, X.; Liu, G.; Yamato, K.; Shen, Y.; Cheng, R.; Wei, X.; Bai, W.; Gao, Y.; Li, H.; Liu, Y.; et al. Self-assembling subnanometer pores with unusual mass-transport properties. Nat. Commun. 2012, 3, 949. [CrossRef] [PubMed]

34. Jeon, H.-G.; Jung, J.Y.; Kang, P.; Choi, M.-G.; Jeong, K.-S. Folding-Generated Molecular Tubes Containing One-Dimensional Water Chains. J. Am. Chem. Soc. 2016, 138, 92-95. [CrossRef] [PubMed]

35. Loganathan, P.; Naidu, G.; Vigneswaran, S. Mining valuable minerals from seawater: A critical review. Environ. Sci. Water Res. Technol. 2017, 3, 37-53. [CrossRef]

36. Tiwari, G.; Tiwari, R.; Rai, A.K. Cyclodextrins in delivery systems: Applications. J. Pharm. Bioallied Sci. 2010, 2, 72-79. [CrossRef] [PubMed]

37. Shieh, W.J.; Hedges, A.R. Properties and Applications of Cyclodextrins. J. Macromol. Sci. Part A 1996, 33, 673-683. [CrossRef]

38. Del Valle, E.M.M. Cyclodextrins and their uses: A review. Process Biochem. 2004, 39, 1033-1046. [CrossRef]

39. González-Pérez, A. Reversible DNA compaction. Curr. Top. Med. Chem. 2014, 14, 766-773. [CrossRef] [PubMed]

40. Wenz, G.; Han, B.-H.; Müller, A. Cyclodextrin Rotaxanes and Polyrotaxanes. Chem. Rev. 2006, 106, $782-817$. [CrossRef] [PubMed]

41. González-Pérez, A.; Carlstedt, J.; Dias, R.S.; Lindman, B. Cyclodextrins in DNA decompaction. Colloids Surf. $B$ Biointerfaces 2010, 76, 20-27. [CrossRef] [PubMed]

42. Chui, J.K.W.; Fyles, T.M. Cyclodextrin ion channels. Org. Biomol. Chem. 2014, 12, 3622-3634. [CrossRef] [PubMed]

43. Iqbal, K.S.J.; Cragg, P.J. Transmembraneion transport by calixarenes and their derivatives. Dalton Trans. 2007, 26-32. [CrossRef] [PubMed]

44. Lawal, O.; Iqbal, K.S.J.; Mohamadi, A.; Razavi, P.; Dodd, H.T.; Allen, M.C.; Siddiqui, S.; Fucassi, F.; Cragg, P.J. An artificial sodium ion channel from calix[4]arene in the 1,3-alternate conformation. Supramol. Chem. 2009, 21, 55-60. [CrossRef]

45. Martos, V.; Bell, S.C.; Santos, E.; Isacoff, E.Y.; Trauner, D.; de Mendoza, J. Molecular recognition and self-assembly special feature: Calix[4]arene-based conical-shaped ligands for voltage-dependent potassium channels. Proc. Natl. Acad. Sci. USA 2009, 106, 10482-10486. [CrossRef] [PubMed]

46. Costa, P.J.; Marques, I.; Félix, V. Interaction of a calix[4]arene derivative with a DOPC bilayer: Biomolecular simulations towards chloride transport. Biochim. Biophys. Acta 2014, 1838, 890-901. [CrossRef] [PubMed]

47. Ghadiri, M.R.; Granja, J.R.; Buehler, L.K. Artificial transmembrane ion channels from self-assembling peptide nanotubes. Nature 1994, 369, 301-304. [CrossRef] [PubMed]

48. Fyles, T.M.; Colombini, M.; Müllen, K.; Sieffert, M.; Heald, T.; Regen, S.L.; Park, C.-S.; Koh, D.-S.; Kim, K.; Wilcoxen, K.M.; et al. Synthetic ion channels in bilayer membranes. Chem. Soc. Rev. 2007, 36, 335-347. [CrossRef] [PubMed]

49. Engels, M.; Bashford, D.; Ghadiri, M.R. Structure and Dynamics of Self-Assembling Peptide Nanotubes and the Channel-Mediated Water Organization and Self-Diffusion. A Molecular Dynamics Study. J. Am. Chem. Soc. 1995, 117, 9151-9158. [CrossRef]

50. Zhao, X.; Pan, F.; Xu, H.; Yaseen, M.; Shan, H.; Hauser, C.A.E.; Zhang, S.; Lu, J.R. Molecular self-assembly and applications of designer peptide amphiphiles. Chem. Soc. Rev. 2010, 39, 3480-3498. [CrossRef] [PubMed]

51. De la Rica, R.; Matsui, H. Applications of peptide and protein-based materials in bionanotechnology. Chem. Soc. Rev. 2010, 39, 3499-3509. [CrossRef] [PubMed]

52. González-Pérez, A. Proteins and Peptides in Biomimetic Polymeric Membranes. In Proteins in Solution and at Interfaces; John Wiley \& Sons, Inc.: Hoboken, NJ, USA, 2013; pp. 283-290.

53. Garcia-Fandiño, R.; Calvelo, M.; Granja, J.R.; Granja, J.R. Pore- and Channel-Forming Peptides and Their Mimetics. In Comprehensive Supramolecular Chemistry II; Elsevier: New York, NY, USA, 2017; pp. 539-573.

54. Howorka, S. Building membrane nanopores. Nat. Nanotechnol. 2017, 12, 619-630. [CrossRef] [PubMed]

55. Rosenberg, P.A.; Finkelstein, A. Water permeability of gramicidin A-treated lipid bilayer membranes. J. Gen. Physiol. 1978, 72, 341-350. [CrossRef] [PubMed] 
56. Saeki, D.; Yamashita, T.; Fujii, A.; Matsuyama, H. Reverse osmosis membranes based on a supported lipid bilayer with gramicidin A water channels. Desalination 2015, 375, 48-53. [CrossRef]

57. Wang, Z.; Wu, A.; Colombi Ciacchi, L.; Wei, G. Recent Advances in Nanoporous Membranes for Water Purification. Nanomaterials 2018, 8, 65. [CrossRef] [PubMed]

58. Kawano, R.; Horike, N.; Hijikata, Y.; Kondo, M.; Carné-Sánchez, A.; Larpent, P.; Ikemura, S.; Osaki, T.; Kamiya, K.; Kitagawa, S.; et al. Metal-Organic Cuboctahedra for Synthetic Ion Channels with Multiple Conductance States. Chem 2017, 2, 393-403. [CrossRef]

59. Wang, D.; Zhang, Y.; Liu, D. DNA nanochannels. F1000Research 2017, 6, 503. [CrossRef] [PubMed]

60. Göpfrich, K.; Li, C.-Y.; Ricci, M.; Bhamidimarri, S.P.; Yoo, J.; Gyenes, B.; Ohmann, A.; Winterhalter, M.; Aksimentiev, A.; Keyser, U.F. Large-Conductance Transmembrane Porin Made from DNA Origami. ACS Nano 2016, 10, 8207-8214. [CrossRef] [PubMed]

61. Cohen-Tanugi, D.; Grossman, J.C. Water Desalination across Nanoporous Graphene. Nano Lett. 2012, 12, 3602-3608. [CrossRef] [PubMed]

62. Dervin, S.; Dionysiou, D.D.; Pillai, S.C. 2D nanostructures for water purification: Graphene and beyond. Nanoscale 2016, 8, 15115-15131. [CrossRef] [PubMed]

63. Heiranian, M.; Farimani, A.B.; Aluru, N.R. Water desalination with a single-layer MoS2 nanopore. Nat. Commun. 2015, 6, 8616. [CrossRef] [PubMed]

64. Andrew, A.; Baker, R. Membranes from academia to industry. Nat. Mater. 2017, 16, 280-282.

(C) 2018 by the authors. Licensee MDPI, Basel, Switzerland. This article is an open access article distributed under the terms and conditions of the Creative Commons Attribution (CC BY) license (http://creativecommons.org/licenses/by/4.0/). 